\title{
A NATURAL INFRAGENERIC CLASSIFICATION FOR CICER (LEGUMINOSAE, CICEREAE)
}

\author{
A.M.R. DAVIES ${ }^{1}$, N. MAXTED ${ }^{2} \&$ L.J.G. VAN DER MAESEN ${ }^{3}$
}

\begin{abstract}
SUMMARY
A comprehensive morphological survey and analysis of all taxonomically recognised wild species of Cicer L. (Leguminosae, Cicereae) is presented. The data (104 characters from 152 herbarium specimens representing 34 of the 44 recognised taxa in the genus Cicer with supplementary data for the remaining taxa taken from the literature) were analysed using multivariate statistics (cluster analysis, factor analysis and ordination techniques). The results are discussed in the context of extant classifications and the re-organisation of a novel infrageneric classification also incorporating information from published genetic data. A revised classification with 3 subgenera, 5 sections and 2 series is proposed.
\end{abstract}

Key words: Leguminosae, Cicereae, infrageneric classification, morphology, wild chickpeas.

\section{INTRODUCTION}

The genus Cicer (Leguminosae, Cicereae) comprises 44 species (C. tragacanthoides has two varieties), 9 annuals and 35 perennials (Van der Maesen et al., 2007), two more than Coles et al. were able to report (1998), which have a centre of diversity in south-western Asia, with remote, endemic species found in Morocco and the Canary Islands (Van der Maesen, 1987). The genus is the only member of the tribe Cicereae Alef., subfamily Papilionoideae, family Leguminosae. It was historically included in the legume tribe Vicieae (Bronn) DC., but Kupicha (1977) presented detailed taxonomic evidence to support the tribal distinction of the genus from the other Vicieae genera: Vicia L., Pisum L., Lens Adans., Lathyrus L. and Vavilovia Fed. To this end Kupicha (1977) reinstated the monogeneric tribe Cicereae originally proposed by Alefeld (1859) and provided a detailed generic description (Kupicha, 1981). The most widely known species is the cultivated chickpea, Cicer arietinum L. Much attention has focussed on the cultivated form and its subspecific taxa in the past. However, in more recent years the focus of interest has broadened to include all the annual species because of the search for various beneficial crop-related traits in wild Cicer species (Muehlbauer et al., 1994; Hannan et al., 2000). A consequence of this research bias is that the perennial species, largely located in remote Central Asia, have been under-collected and taxonomically neglected until recently. After the genus was revised by Van der Maesen (1972), several

1) Institut für Systematische Botanik, Menzinger Strasse 67, München, Germany.

2) University of Birmingham, School of Biosciences, Edgbaston, Birmingham, B15 2TT, United Kingdom.

3) Nationaal Herbarium Nederland, Wageningen branch (Herbarium Vadense), Biosystematics Group, Wageningen University, Generaal Foulkesweg 37, 6703 BL Wageningen, The Netherlands. 


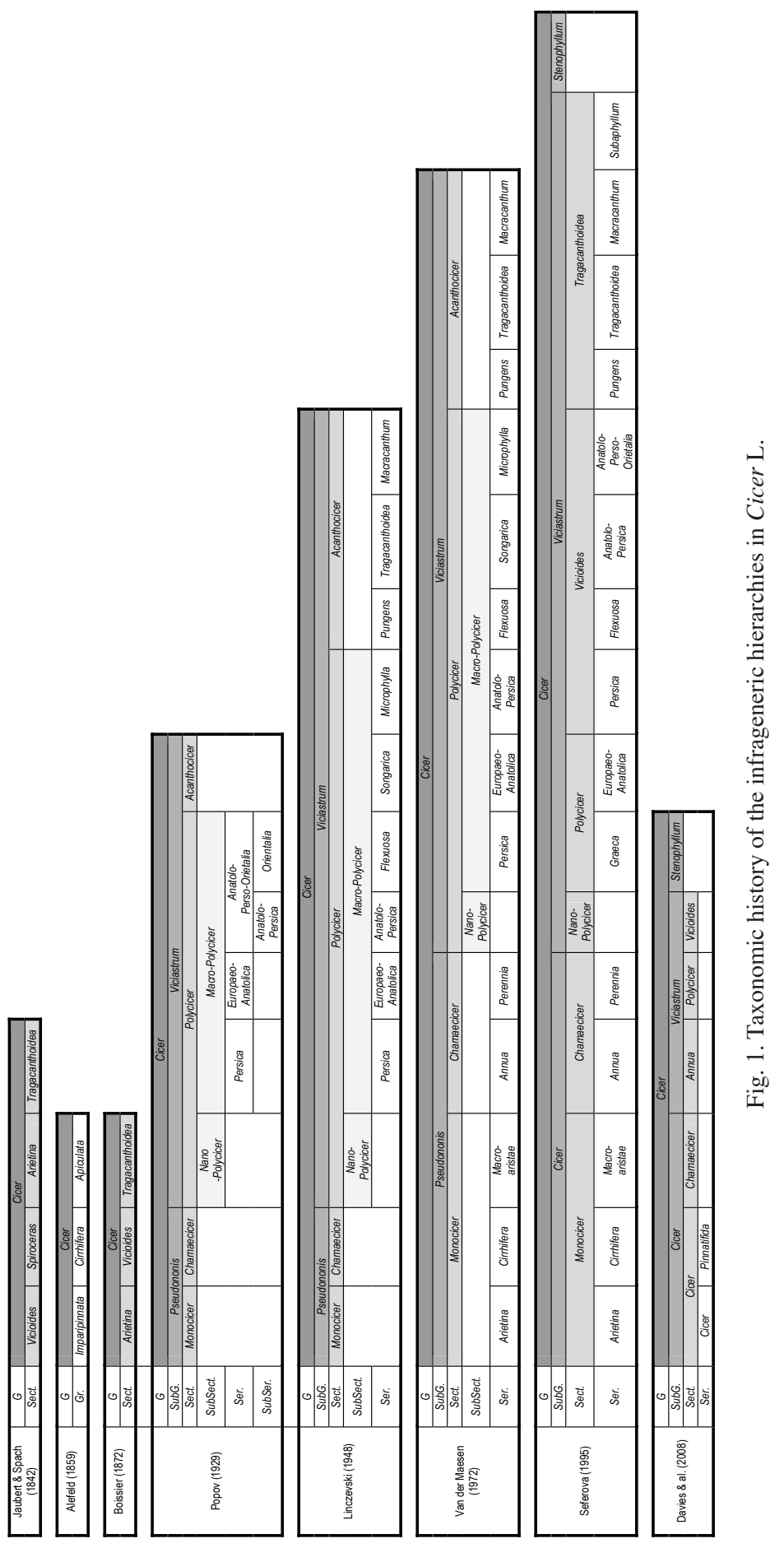


new Cicer species have been described. The current exploitation interest and addition of new taxa have resulted in the need for a revised classification of the genus. It has been increasingly clear that the traditionally defined infrageneric groupings result in non-monophyletic species, subgenera and sections (e.g., Rajesh et al., 2003; Frediani \& Caputo, 2005). The general aim of this research was to clarify the relationships between Cicer taxa by combining multivariate analytical approaches with morphological data and the published genetic data and produce a revised natural classification that will aid future collection, conservation and utilisation of the genus. Interactive keys and short descriptions have been published by Van der Maesen et al. (2007), previous to the present paper of which publication was inadvertently delayed.

The genus Cicer was first studied in detail by Jaubert \& Spach (1842), who described four sections, Arietina, Vicioides, Spiroceras and Tragacanthoides based on woodiness and terminal structure of the rachis (presence of a leaflet, spine or tendril). The infrageneric classification of Cicer over the last 165 years is illustrated in Fig. 1. Both formal and informal (Alefeld, 1859) hierarchies are included, as are the nomenclatural invalid series of Linczevski (1948). Boissier (1872) adopted this system but merged sections Vicioides and Spiroceras. Popov (1929) proposed a more detailed classification that subdivided the genus into 2 subgenera and 4 sections, also incorporating subsectional, series and subseries taxa. Linczevski (1948) revised Popov's classification streamlining the divisions within the sections.

The genus was comprehensively revised by Van der Maesen (1972), who extended the work of Popov (1929) and Linczevski (1948). The classification proposed by Van der Maesen contained 2 subgenera, Pseudononis Popov and Viciastrum Popov (distinguished by flower size and calyx morphology) and 4 sections distinguished as follows: Monocicer, annual, small-flowered species with firm, erect to inclined or prostrate stems and imparipinnate leaves, or the rachis terminating in a tendril; Chamaecicer, annual or perennial shrubby species with thin creeping branches and 3-7 leaflets per leaf; Polycicer, the large-flowered perennial species with imparipinnate leaves or tendrilous rachis; and Acanthocicer, large-flowered species with persistent spiny rachis and spinous calyx teeth. The sections are further subdivided into 2 subsections and 14 series. The characters used to divide the series included: standard length, number of pairs of leaflets on the rachis, apical structure of the rachis, number of flowers per inflorescence, bract and stipule characters, arista size and life cycle.

The Cicer taxa present within the former Soviet Union were reviewed by Seferova in 1995. As well as lectotypifying the supraspecific ranks, she replaced some illegitimate names, effectively publishing others and drew attention to several new Central Asian species. The amended classification includes 3 subgenera, 8 sections and 13 series. The characters she used to distinguish taxa are primarily the ones used previously by Van der Maesen (1972). The most significant difference between the classifications of Van der Maesen (1972) and Seferova (1995) is seen in the sections of subgenus Cicer, and sections Polycicer Popov, Nanopolycicer (Popov) Seferova and Vicioides Jaub. \& Spach of subgenus Viciastrum, and in the series divisions of section Tragacanthoidea Jaub. \& Spach.

Both the Van der Maesen (1972) and Seferova (1995) classifications were produced using non-numeric techniques. Seferova proposed several nomenclatural changes to the taxa accepted by Van der Maesen (1972), reducing several entities to synonyms 
as follows: $C$. macracanthum Popov (=C. incanum Korotkova); $C$. grande (Popov) Korotkova ( $=C$. paucijugum Nevski); $C$. macracanthum subsp. acanthophyllum (Boriss.) Seferova (=C. acanthophyllum Boriss. $=C$. garanicum Boriss.); C. flexuosum subsp. mogoltavicum Popov (= C. mogoltavicum Popov). In addition, several new Cicer species have been described since 1972: C. canariense A.G. Guerra \& G.P. Lewis (Santos Guerra \& Lewis, 1985); C. heterophyllum Contandr., Pamukç. \& Quézel (Contandriopoulos et al., 1972); C. reticulatum Ladiz. (Ladizinsky, 1975); C. luteum Rassulova \& Sharipova (Rassulova \& Sharipova, 1992); C. laetum Rassulova \& Sharipova (Rassulova \& Sharipova, 1978) and C. rassuloviae Lincz. (Linczevski, 1948). The infrageneric structure of Cicer has become progressively more unwieldy over time. The complex hierarchy attempts to justify the perceived interspecific variation based on species whose infraspecific variation is often poorly understood.

New information from biochemistry, plant breeding and especially genetics have highlighted the weaknesses in the current infrageneric hierarchy, indicating that the existing perception of species relationships based on the congruence of a few characters cannot adequately explain true natural relationships in the genus.

Therefore, to clarify the relationships between taxa within the genus Cicer it is time to update and re-evaluate the infrageneric classification using objective techniques.

\section{MATERIALS AND METHODS}

Forty-one species and four varieties were included in the analysis. The characteristics of thirty-three species were recorded from 152 herbarium specimens and the remaining taxa were scored from literature sources. Herbarium specimens were loaned from BM, E, K and WAG (abbreviations follow Holmgren et al., 1990). Author names follow Brummitt \& Powell (1992). A species citation list is given in the Identification List at the end of this article. The character set was compiled from the literature (Davis, 1970; Contandriopoulos et al., 1972; Van der Maesen, 1972, 1987; Kupicha, 1977; Coles, 1993; Maxted, 1993) and personal observations of the specimens. The data matrix is provided in Table 1 and the characters and character states recognised are listed in Table 2. The final character list contained 104 characters, including: 14 habit and stem characters, 36 vegetative characters, 25 inflorescence characters, 16 pollen, anthers, pods and seeds characters and 13 characters covering features such as phenology, altitude and chromosome number. Many different types of character were recorded. Continuous data, usually considered to be intrinsically ordered when coded into 'discrete' states, were scored as numbered states accounting for the natural ranges of variation. E.g. rachis length (character 19; Table 2) was seen to vary in three natural clusters throughout the data set: those species whose rachis was persistently less than $40 \mathrm{~mm}$ long, those with rachis' between 40 and $70 \mathrm{~mm}$ long and those with long rachis' over $70 \mathrm{~mm}$. All characters were scored as either binary or multistate but considered as unordered in the final analysis. The code of 9 was used to represent missing data. Where appropriate during the analyses non-variable characters, and characters for which there was a lot of missing data (e.g. characters 86-90, 93-104), were omitted.

Within Cicer there have been several non-morphologically-based investigations of species relationships, particularly among the annual species. Studies have covered molecular variation (Kazan \& Muehlbauer, 1991; Ahmad \& Slinkard, 1992; Ahmad et al., 


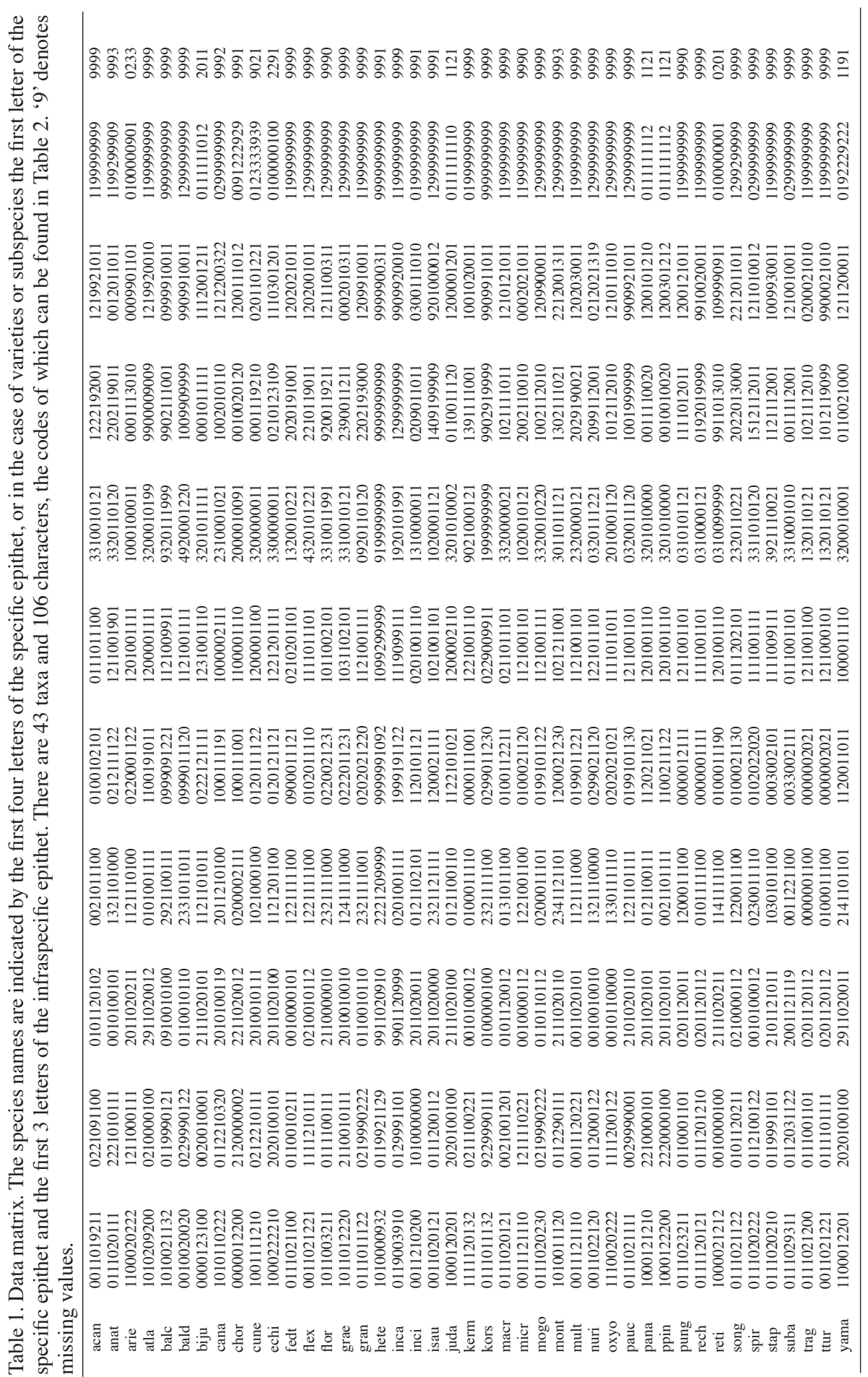


Table 2. Description of characters and their states.

1 Woodiness

2 Stem robustness

3 Growth cycle

4 Habit

5 Form

6 Branching

7 Stem hair density (hairs $/ \mathrm{mm}^{2}$ )

8 Stem hair type

9 Stem height (mean $\mathrm{cm}$ )

10 Stem height (range $\mathrm{cm}$ )

11 Pigmentation

12 Stem orientation

13 Stem surface ribbed

14 Internodal length (mean mm)

15 Internodal length (range $\mathrm{mm}$ )

16 Leaf hair length ( $\mathrm{mm})$

17 Leaf arrangement

18 Number of pairs of leaflets

19 Rachis length (mm)

20 Leaf spacing on rachis (character 18, 19)

21 Leaf shape outline

22 Rachis rolled

23 Rachis apex - spine

24 Rachis apex - tendril

25 Rachis apex - leaflet

26 Tendril structure

27 Leaflet form

28 Phyllotaxy

29 Leaflet margins

30 Leaflet margin serrations

31 Leaflet length ( $\mathrm{mm})$

32 Leaflet width $(\mathrm{mm})$

33 Leaflet shape

34 Leaflets flabellate

35 Leaflet apex

36 Leaflet base

37 Leaflet teeth shape

38 Terminal apical spine

39 Midrib tooth

40 Midrib tooth

41 Midrib tooth

42 Number of teeth per leaflet

43 Leaflet surface ribbed

44 Leaflet surface pubescent

45 Leaflet teeth apices

46 Leaflet petioles

47 Stipules

48 Stipule length (mm)

49 Nr. teeth on stipules

50 Stipule outline

51 Stipule (basal) v. leaflet size

52 Number of flowers / raceme

53 Peduncle length ( $\mathrm{mm})$

54 Pedicel length $(\mathrm{mm})$

55 Arista form
0 = woody $; 1=$ not woody

$0=$ slender; $1=$ sturdy

$0=$ annual; 1 = perennial

$0=$ herb; $1=$ shrub; 2 = climber

$0=$ erect $; 1=$ semi-erect; $2=$ procumbent

$0=$ simple $; 1=$ sparse $; 2=$ secondary

$0=<20 ; 1=20-30 ; 2=31-40 ; 3=>40$

$0=$ eglandular $; 1=$ glandular $; 2=$ both $;=$ glabrous

$0=<20 ; 1=20-30 ; 2=31-40 ; 3=>40$

$0=<10 ; 1=10-20 ; 2=>20$

$0=$ absent; $1=$ sometimes; 2 = always

$0=$ straight $; 1=$ flexuous $; 2=$ both

$0=$ prominently; 1 = ribbed 2 = faintly

$0=<20 ; 1=20-30 ; 2=>30$

$0=<10 ; 1=10-20 ; 2=>20$

$0=<0.5 ; 1=0.5-0.89 ; 2=>0.9,3=$ no hairs

$0=$ imparipinnate $; 1=$ paripinnate

$0=1-4 ; 1=3-10 ; 2=7-15 ; 3=>20$

$0=<40 ; 1=40-70 ; 2=>70$

$0=1-5 ; 1=6-11 ; 2=\geq 12$

$0=$ decrescent $; 1=$ increscent 2 = equal

0 = loosely; 1 = tightly; 2 = not

$0=$ present; $1=$ absent

$0=$ present $; 1=$ absent

$0=$ present $1=$ absent

$0=$ simple $; 1=$ branched $; 2=$ none

$0=$ laminate $; 1=$ spinose

$0=$ opposite $; 1= \pm$ opposite $; 2$ = alternate

$0=$ doubly incised $; 1=$ incised

$0=$ entire $-2 / 3 ; 1=1 / 2-2 / 3 ; 2=$ apex $-1 / 2$

$0=<5 ; 1=5-10 ; 2=>10$

$0=0-2 ; 1=2-4 ; 2=4-6 ; 3=>6$

$0=$ cuneiform $; 1=$ linear $; 2=$ obovate $3=$ rotund $4=$ elliptic

$0=$ yes $; 1=$ no

$0=$ truncate $; 1=$ rounded $; 2$ acute

$0=$ cuneate $; 1=$ rounded-cuneate $; 2=$ truncate

$0=$ acute $; 1=$ acuminate $/$ triangular $; 2$ = rectangular $/$ cuspidate

$0=$ tendrillous; 1 = inflexed

$0=$ prominent $1=$ not

$0=$ spinose $; 1=$ not

$0=$ recurved; $1=$ not

$0=0-5 ; 1=6-11 ; 2=\geq 12$

$0=\mathrm{U}=\mathrm{L} ; 1=\mathrm{U}>\mathrm{L} ; 2=\mathrm{U}<\mathrm{L} ; 3=$ smooth

$0=\mathrm{U}=\mathrm{L} ; 1=\mathrm{U}>\mathrm{L} ; 2=\mathrm{U}<\mathrm{L} ; 3=$ glabrous

$0=$ spine $; 1=$ mucro; $2=$ none

$0=$ sessile $(0-0.3) ; 1=$ subsessile $(0.4-0.6)$;

2 = petiolate $(0.7-1.0)$

$0=$ spiny $; 1=$ laminate $; 2$ both

$0=0.0-2.9 ; 1=3.0-5.9 ; 2=>6.0$

$0=1$ only $1=1-3 ; 2=2-6 ; 3=>6$

$0=$ flabellate $/$ oblique $;=$ ovate $/$ lanceolate $; 2$ = triangular

$0=$ equal or bigger; $1=$ smaller

$0=$ some many flowered; $1=$ none more than 2 -flowered;

2 = always 1 -flowered

$0=0-15 ; 1=16-30 ; 2=31-45 ; 3=>46$

$0=\leq 5 ; 1=\geq 6$

$0=$ spine $; 1=$ leaflet $2=$ both 


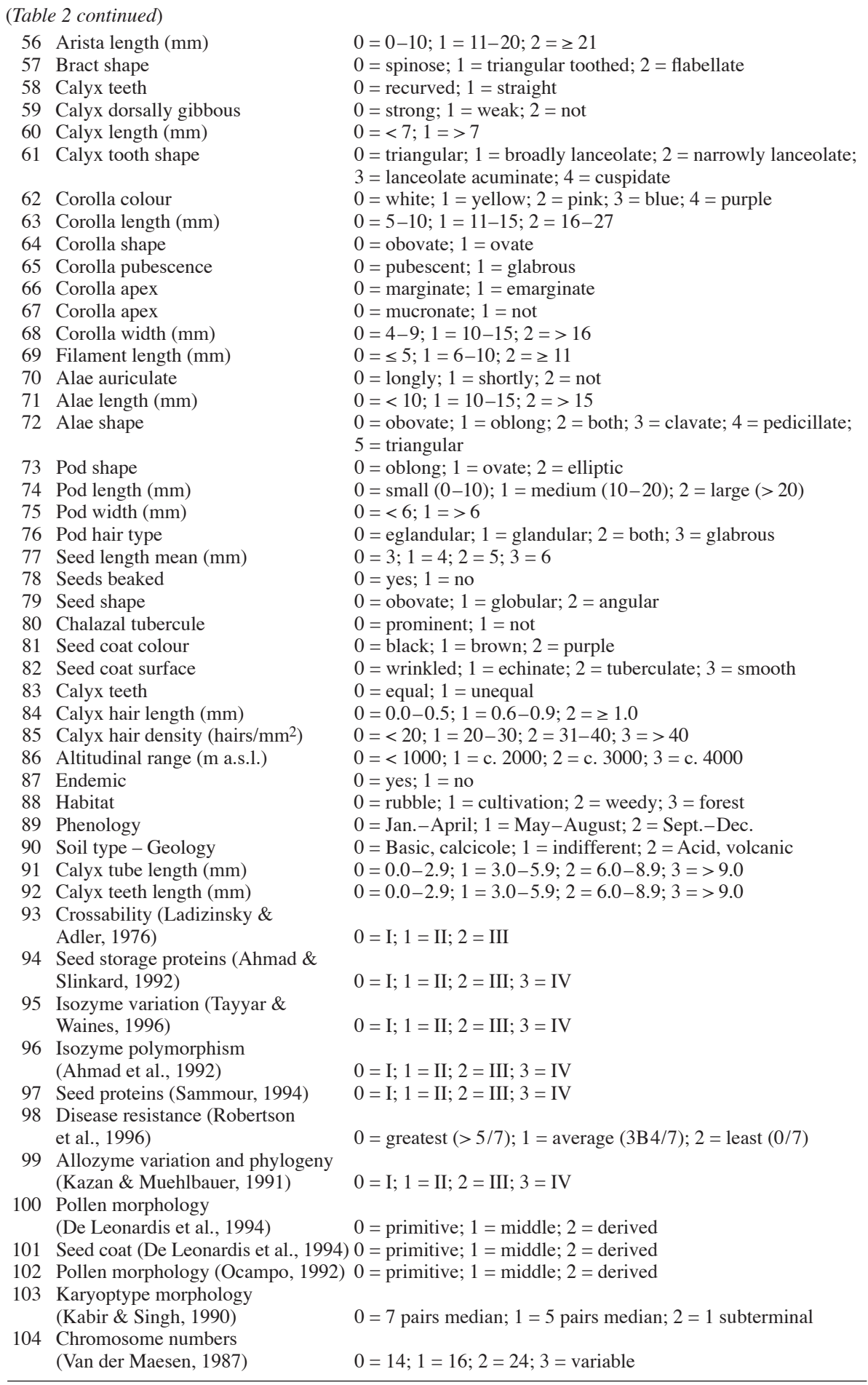


1992, Sammour, 1994; Tayyar \& Waines, 1996; Javadi, 2004; Javadi \& Yamaguchi 2004a, b; Frediani \& Caputo, 2005, Javadi et al., 2007), seed coat and plumule morphology (Javadi \& Yamaguchi, 2004c), palynology (Ocampo et al., 1992; De Leonardis et al., 1994), cytology (Van der Maesen, 1987; Kabir \& Singh, 1990), crossability groups (Ladizinsky \& Adler, 1976) and disease resistance (Robertson et al., 1996). However, these studies have rarely attempted a genus-wide examination and have generally focussed on the annual species closely related to cultivated chickpeas. Where appropriate, their results are included in the taximetric analysis and in some cases they have been central in drawing overall conclusions for interspecific relationships.

The data set was initially analysed using the program NTSYS (Rohlf, 1995) - Cluster Analysis. The program used Sneath's Simple Matching Coefficient to calculate an Euclidean distance based similarity matrix and this was analysed using the UPGMA clustering method. Cophenetic correlation can be calculated and used as an indication of degree of fit between the similarity matrix and the cophenetic value matrix based on the UPGMA cluster file. Rohlf (1995) defines the goodness of fit as a correlation coefficient $\boldsymbol{r}$, based on the Mantel statistic $\boldsymbol{Z}$. A poor fit is deemed $a$ priori to be in the region of $r=0.7$ to 0.8 , good to very good being $r=0.8$. Rohlf considers that for more than 12 OTUs (Operational Taxonomic Unit) a correlation greater than 0.5 will be statistically significant at the $99 \%$ level. The correlation is subjected to a Student's t-test to assess statistical significance. Note that the significance tests are biased because the matrices being compared are not fully independent.

Principle Components Analysis (PCA) is an ordination analysis technique that attempts to replace a large set of variables by selecting a smaller subset of variables which best summarizes the larger set. The two-fold advantage of this technique is the simplification of a large data set by highlighting significant sources of variance - in this case the characters, and the extraction of a relationship structure between the variables - in this study the species inter-relationships. The relationships between OTUs in low dimensional space (2-D or 3-D) and the efficiency of the true separation of points can be assessed by superimposing a Minimum Spanning Tree (MST) onto the first two principle component axes. Multiple methods of analysis were used because, as pointed out by Duncan \& Baum (1981), different algorithms bias the results in different ways. The use of different methods of analysis allows the verification of the validity of the groups suggested by these analyses. Restricted PCA analyses on different subsets of the data allowed the selection of characters contributing the most variation separating the subgenera, sections and series. The ten most highly ranked characters (eigenvectors) for the first two components in three PCA runs (total data set, the Cicer annuals and the Cicer perennials) were selected and cross-referenced to the original data sets for systematic usefulness. These characters form the basis of the descriptions for the supraspecific ranks in the nomenclatural analysis.

\section{RESULTS}

\section{Cluster analysis}

The results of the cluster analysis are shown in Fig. 2. The species are divided into two clusters at the $46 \%$ level. One group, group A, contains all 9 annual species with 3 perennials: $C$. canariense, $C$. incisum and $C$. atlanticum. The second group, group B, 


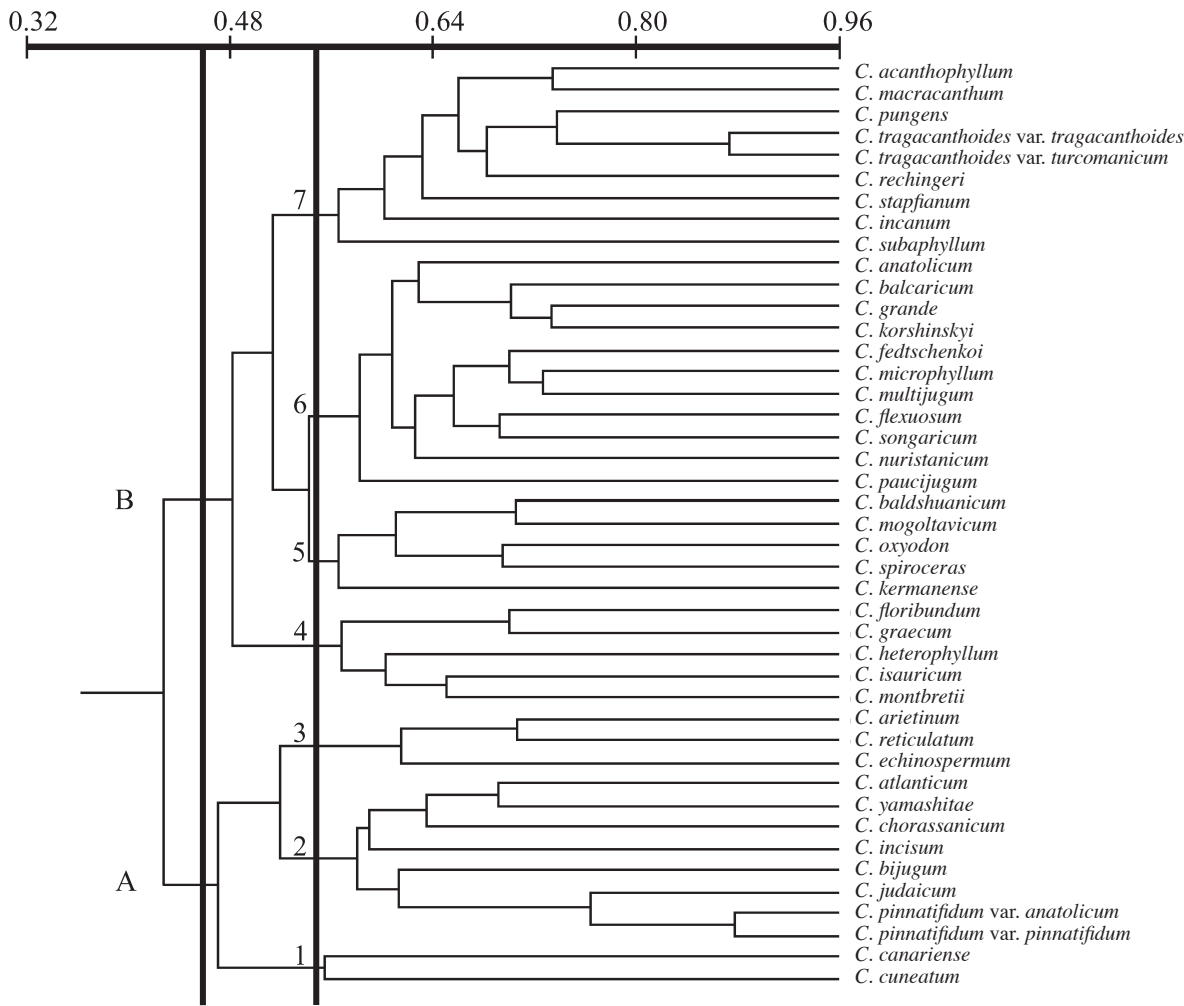

Fig. 2. Phenogram of all Cicer species based on 104 characters.

covers the remaining 29 species, which are all perennials. As similarity increases to $53 \%$ the taxa form 7 further clusters (numbered from 1 to 7 in Fig. 2). Three of these clusters fall under group $\mathrm{A}$, and the remaining 4 into group $\mathrm{B}$. The division of taxa into these clusters is as follows:

\section{Cicer canariense and C. cuneatum.}

The two varieties of $C$. pinnatifidum are most similar and these are most closely associated with $C$. judaicum and $C$. bijugum. The remaining species are $C$. incisum, C. chorassanicum, C. yamashitae and C. atlanticum.

Three closely related annual species: $C$. arietinum, $C$. reticulatum and $C$. echinospermum.

Cicer floribundum, C. graecum, $C$. heterophyllum, $C$. isauricum and $C$. montbretii.

Cicer baldshuanicum, C. mogoltavicum, C. oxyodon, C. spiroceras and C. kermanense.

Cicer paucijugum seems somewhat isolated from the other species in the cluster. Cicer nuristanicum, C. songaricum, C. flexuosum, C. multijugum, C. microphyllum and $C$.fedtschenkoi, and more remotely $C$. korshinskyi, C. grande, C. balcaricum and C. anatolicum.

Cicer acanthophyllum, C. macracanthum, C. pungens, C. tragacanthoides (including the two varieties), C. rechingeri, $C$. stapfianum, C. incanum and $C$. subaphyllum. 


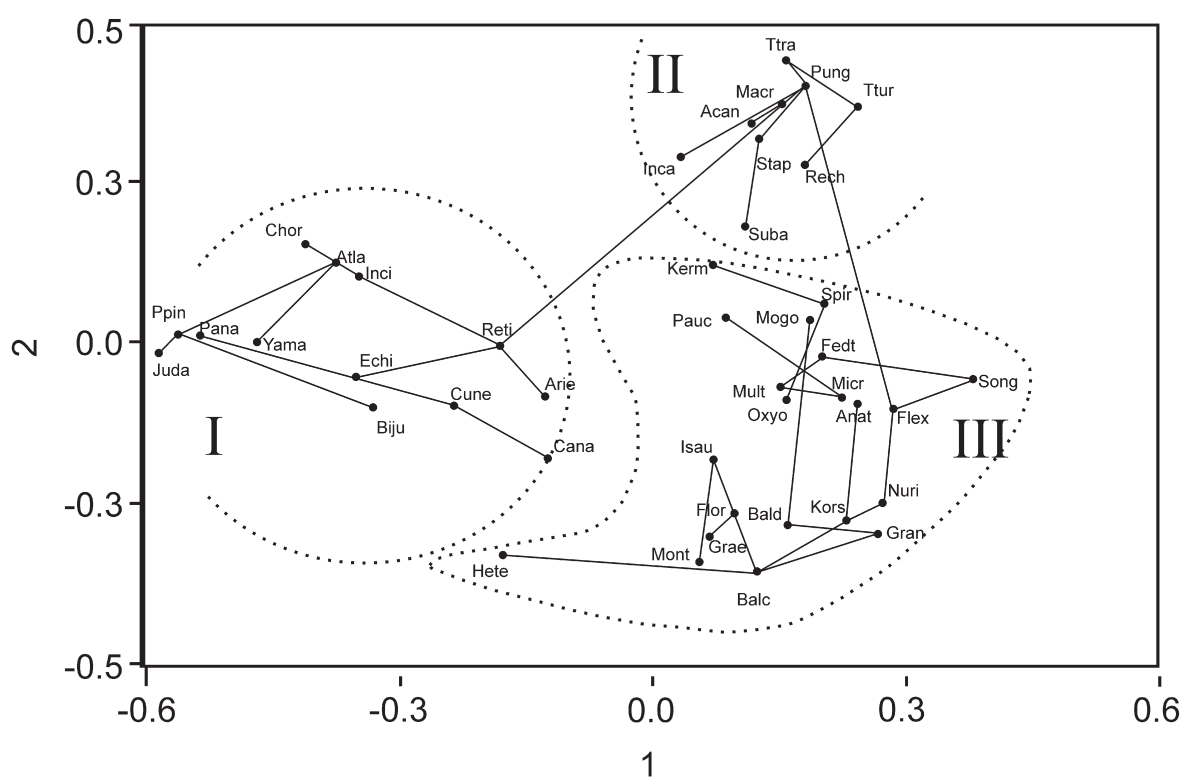

Fig. 3. PCA plot with MST superimposed. Clusters delineated by dotted lines and identified by I, II and III. Species names abbreviated to first four letters of the specific epithet, or in the case of subspecific epithets, the first letter of the specific name and the first three letters of the subspecific epithet, i.e. 'acan' $=$ C. acanthophyllum; 'ttur' = C. tragacanthoides var. turcomanicum Popov.

\section{Cophenetic correlation and principle coordinates analysis}

The results of the multivariate techniques PCA and MST are shown in Fig. 3. The Mantel statistic $Z$ gives $r=-0.81$, with the $t$-test giving $\mathrm{t}=-19.37$ and $\mathrm{p}<0.000$, which indicates the result is a statistically reliable representation of the relationships between the OTUs. The PCA plot of the first two Principal Coordinates with a superimposed MST reinforces the preliminary groupings suggested by the cluster analysis. Three main clusters can be seen (identified in Fig. 3 by the roman numerals given here and delineated by a dotted line) and the membership of each is as follows:

Cluster I: Cicer arietinum, C. atlanticum, C. bijugum, C. canariense, C. chorassanicum, C. cuneatum, C. echinospermum, C. incisum, C. judaicum, C. pinnatifidum var. anatolicum, C. pinnatifidum var. pinnatifidum, C. reticulatum and C. yamashitae.

Cluster II: Cicer acanthophyllum, C. incanum, C. macracanthum, C. pungens, C.rechingeri, C. stapfianum, C. subaphyllum, C. tragacanthoides var. turcomanicum and $C$. tragacanthoides var. tragacanthoides.

Cluster III: Cicer anatolicum, C. balcaricum, C. baldshuanicum, C. fedtschenkoi, C. flexuosum, C. floribundum, C. graecum, C. grande, C. heterophyllum, C. isauricum, C. kermanense, C. korshinskyi, C. microphyllum, C. mogoltavicum, C. montbretii, C. multijugum, C. nuristanicum, C. oxyodon, C. paucijugum, $C$. songaricum and $C$. spiroceras. 
Table 3. Eigenvalues, \% variance and cumulative variance after PCA for the first 3 components in the analyses (PCA 1 'all taxa' - 104 characters, 43 species; PCA 2 'Cicer annuals' - 104 characters, 11 species; PCA 3 'Cicer perennials' - 92 characters, 32 species).

\begin{tabular}{|c|c|c|c|c|}
\hline & Component & Eigenvalue & $\%$ Variance & $\begin{array}{c}\text { Cumulative } \\
\text { Variance }\end{array}$ \\
\hline \multirow{3}{*}{$\bar{z} \underset{\tilde{x}}{\tilde{x}}$} & 1 & 15.14 & 16.46 & 16.46 \\
\hline & 2 & 10.51 & 11.42 & 27.88 \\
\hline & 3 & 5.09 & 5.54 & 33.42 \\
\hline \multirow{3}{*}{ 离节 } & 1 & 19.58 & 21.05 & 21.05 \\
\hline & 2 & 16.55 & 17.79 & 38.84 \\
\hline & 3 & 14.14 & 15.20 & 54.05 \\
\hline \multirow{3}{*}{ 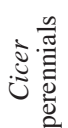 } & 1 & 13.55 & 14.73 & 14.73 \\
\hline & 2 & 9.14 & 9.93 & 24.67 \\
\hline & 3 & 6.79 & 7.39 & 32.05 \\
\hline
\end{tabular}

\section{Character selection for supraspecific descriptions}

The cumulative variance accounted for in the first two component axes was relatively low in all analyses (All taxa $=28 \%$; Annuals $=38 \%$; Perennials $=25 \%$ ). This indicates that there is a lot of 'noise' in the data set, i.e., the characters are intrinsically variable (Table 3, 4).

Some characters in PCA 1 are principally important in defining the clusters among the perennials species such as leaflet characters and corolla size. Other characters are more important in circumscribing the annuals such as rachis apex or stem height. The remaining characters such as filament length, life cycle, habit, calyx tube length, presence of a terminal leaflet and leaflet shape could be considered as potential descriptors for subgeneric groups. Within the subgenera, the characters listed for PCA 2 and PCA 3 can be considered as potential descriptors for the sections and series.

\section{DISCUSSION}

\section{Morphological analysis and extant taxonomy}

Considering the results of the cluster and PCA analyses together, one overall picture of resemblance emerges which is compared and contrasted to previous classifications. Group A in Fig. 2 and Cluster I in Fig. 3 are identical and this grouping largely corresponds to subgenus Pseudononis Popov. This cluster contains all the annual and 3 perennial species and is composed of 3 or 4 subclusters which could be regarded as equivalent to sectional and series divisions within the subgenus.

The first subcluster of $C$. arietinum (the crop chickpea), C. reticulatum (the crop progenitor) and C. echinospermum are closely related species (see below) and this subcluster is directly referable to series Arietina. This grouping is supported by nearly all previous 
Table 4. Character list of ten characters on the first two component axes with the highest \pm ranking eigenvectors for each PCA analysis.

\begin{tabular}{|c|c|c|c|c|c|}
\hline \multicolumn{2}{|c|}{ PCA 1 'All taxa' } & \multicolumn{2}{|c|}{ PCA 2 'Cicer annuals' } & \multicolumn{2}{|c|}{ PCA 3 'Cicer perennials' } \\
\hline cpt1 & cpt 2 & cpt1 & cpt2 & cpt1 & cpt2 \\
\hline Growth cycle & $\begin{array}{l}\text { Rachis apex } \\
\text { spine }\end{array}$ & Phyllotaxy & Internodes length & Leaflet length & $\begin{array}{l}\text { Leaf shape } \\
\text { outline }\end{array}$ \\
\hline Standard length & Leaflet length & Seed length & $\begin{array}{l}\text { Calyx dorsally } \\
\text { gibbous }\end{array}$ & Rachis apex spine & $\begin{array}{l}\text { Midrib tooth } \\
\text { recurved }\end{array}$ \\
\hline Filament length & $\begin{array}{l}\text { Number teeth } \\
\text { per leaflet }\end{array}$ & Stem height & Tendril structure & Leaflet petioles & Standard length \\
\hline Leaf shape outline & Stipules laminate & Seed coat surface & Rachis apex tendril & Leaf arrangement & Standard width \\
\hline Standard width & Leaf arrangement & Leaflet base & Habit & Leaflet width & $\begin{array}{l}\text { Calyx hair } \\
\text { density }\end{array}$ \\
\hline Alae length & $\begin{array}{l}\text { Rachis apex } \\
\text { leaflet }\end{array}$ & $\begin{array}{l}\text { Allozyme } \\
\text { variation (Kazan \& } \\
\& \text { Muehlbauer, 1991) }\end{array}$ & Seed coat colour & $\begin{array}{l}\text { Number teeth } \\
\text { per leaflet }\end{array}$ & Branching \\
\hline Calyx tube length & $\begin{array}{l}\text { Leaflet margins } \\
\text { serrations }\end{array}$ & $\begin{array}{l}\text { Isozyme poly- } \\
\text { morphism (Ahmad } \\
\text { et al., 1992) }\end{array}$ & Rachis length & Stipules laminate & Form \\
\hline Habit & Leaflet petioles & $\begin{array}{l}\text { Isozyme variation } \\
\text { (Tayyar \& Waines, } \\
\text { 1996) }\end{array}$ & $\begin{array}{l}\text { Seed storage } \\
\text { proteins (Ahmad \& } \\
\text { Slinkard, 1992) }\end{array}$ & $\begin{array}{l}\text { Leaflet margins } \\
\text { serrations }\end{array}$ & Alae length \\
\hline Stem height & Leaflet width & $\begin{array}{l}\text { Midrib tooth } \\
\text { spinous }\end{array}$ & $\begin{array}{l}\text { Seed proteins } \\
\text { (Sammour, 1994) }\end{array}$ & Calyx teeth length & $\begin{array}{l}\text { Leaf spacing } \\
\text { on rachis }\end{array}$ \\
\hline Pigmentation & Leaflet shape & Calyx length & $\begin{array}{l}\text { Crossability } \\
\text { (Ladizinsky \& } \\
\text { Adler, 1976) }\end{array}$ & Calyx hair length & $\begin{array}{l}\text { Peduncle } \\
\text { lenght }\end{array}$ \\
\hline
\end{tabular}

studies and is reflected by results in crossing experiments (Ladizinsky \& Adler, 1976), seed proteins (Sammour, 1994), seed storage proteins (Ahmad \& Slinkard, 1992), isozyme polymorphism (Ahmad et al., 1992), isozyme polymorphism and genetic distance (Labdi et al., 1996) and karyotype analysis (Ocampo et al., 1992).

The second subcluster of $C$. bijugum, $C$. judaicum and $C$. pinnatifidum is also a well established natural grouping and biochemical and genetic research consistently confirms this association (Ladizinsky \& Adler, 1976; Ahmad et al., 1992; Labdi et al., 1996; Tayyar \& Waines, 1996). The taxa were divided into two series (Macro-aristae Maesen and Pinnatifida Seferova) by Seferova (1995) on the basis of the latter having more leaflets and a marginally smaller standard petal.

The third subcluster is composed of a less cohesive group of species. The close relationship between $C$. chorassanicum and $C$. yamashitae is also supported by the same biochemical and genetic data as the two clusters discussed above. Seed storage protein data (Ahmad \& Slinkard, 1992; Sammour, 1994) singly place $C$. chorassanicum and C. yamashitae respectively within the secondary gene pool, i.e., towards series Pinnatifida, but isozyme polymorphism and calculated genetic distances place these two species together removed from the GP2 (Ahmad et al., 1992; Labdi et al., 1996). These two species also share the same plumule type (PII) distinct from many other species in Cicer (Javadi \& Yamaguchi, 2004c). In contrast to the previously published supraspecific 
hierarchies (Van der Maesen, 1972; Seferova, 1995) that placed both taxa in subgenus Cicer (= Pseudononis) molecular phylogenies based on nrITS, $\operatorname{trnK} / \mathrm{matK}$ and $\operatorname{trnS}$ trnG data (Van der Maesen et al., 2007) indicate that these two closely affiliated taxa should be placed in subgenus Viciastrum. It is also corroborated by ITS data (Frediani \& Caputo, 2005). Cicer chorassanicum is spread over Persia and north/central Afghanistan while C. yamashitae is confined to Afghanistan.

An affinity between the two perennial species $C$. atlanticum and $C$. incisum is clearly indicated by this study. Although $C$. atlanticum is placed in subgenus Viciastrum by some molecular phylogenies (Van der Maesen et al., 2007), which tallies with Popov's allocation using his empirical-geographical system, the morphological data places $C$. atlanticum and C. incisum close together in subgenus Cicer. This is supported by ISSR (Sudupak, 2004), AFLP (Sudupak et al., 2004), allozyme (Sudupak \& Kence, 2004) and RAPD (Sudupak et al., 2002) data based on Cicer species from Turkey. The close specific relationship between $C$. atlanticum and $C$. incisum has previously been noted by Van der Maesen (1972: 19) and Contandriopoulos et al. (1972). Although an African (Moroccan) species, C. atlanticum does not ally itself with the other African taxa in subgenus Stenophylloma (C. canariense and C. cuneatum) in the morphological or molecular analyses; it is placed much closer to $C$. incisum from the eastern Mediterranean / Persia.

Lastly, C. canariense and C. cuneatum are relatively remotely linked to each other and the other species of the cluster. Previous studies place $C$. canariense in a separate monospecific subgenus Stenophyllum A.G. Guerra \& G.P. Lewis, on account of its geographical isolation from other Cicer species and distinctive characteristics. However, this study indicates a similarity to $C$. cuneatum. Cicer cuneatum has previously been loosely linked with the annual species, as the monospecific series Cirrhifera Maesen (1972) or as section Cunecicer Seferova (1995). The distinction of this species has also been indicated by genetic and biochemical studies (Ahmad \& Slinkard, 1992; Ahmad et al., 1992; Sammour, 1994; Labdi et al., 1996; Tayyar \& Waines, 1996). Seed and plumule analysis (Javadi \& Yamaguchi, 2004c) also place these two species close together but at some distance from the other Cicer taxa. Van der Maesen (1987) described C. canariense as being "a vetch-like perennial" having the seedling morphology of C. cuneatum, this indicates close affinities with the tribe Vicieae (Nozzolillo, 1985).

Group B in Fig. 2 and Clusters II and III in Fig. 3 are the same and correspond to the species of subgenus Viciastrum, Cluster II, with a few exceptions, is section Tragacanthoides Jaub. \& Spach. The nine taxa included in the latter section are all high-altitude, xerophytic species from Central Asia. The analysis indicates four subclusters within Cluster II, although the organisation of species in these groups does not precisely follow previous classifications. The grouping of $C$. subaphyllum and C. stapfianum is recognised as series Subaphylla Seferova by Seferova (1995). Cicer incanum, cited as a synonym of $C$. macracanthum by Seferova (1995), was placed in section Polycicer by Van der Maesen although he notes its affinity to C. macracanthum (Van der Maesen, 1972: 23). Here it is a cluster outlier, but care must be taken when interpreting its placement here as the result may be partially due to a large quantity of missing data for this species. The remaining species, $C$. pungens, $C$. tragacanthoides and $C$. rechingeri, are grouped together. Two of the 3 species are given monospecific 
status in series Pungentia and Tragacanthoidea by Seferova (1995), and she groups C. rechingeri with C. macracanthum on the basis of leaflet number, number of flowers on the inflorescences and leaflet shape. However, this distinction is not supported by the results presented here.

Groups 4, 5 and 6 (Fig. 2) and Cluster III (Fig. 3) represent the most complex and least resolved set of species in the genus Cicer. Many taxa have often switched taxonomic position and taxonomic rank. Popov (1929) defined series composition based on geographical distribution; but, as Coles et al. (1998) concluded, many Cicer species are seriously under-collected and their true pattern of distribution is incomplete. However, group B4 is geographically centred on the Greek and Turkish Aegean islands and is referable to section Polycicer. This grouping is supported by the cluster and ordination results as well as karyotype data; C. graecum, C. heterophyllum, C. isauricum and C. montbretii have $2 \mathrm{n}=16$, while $C$. floribundum has $2 \mathrm{n}=14$ (Contandriopoulos et al.,1972).

During the analyses certain taxa appeared to hold consistently stable key positions in the patterns of relationships (see Fig. 3) implying that they held closer affinities between subclusters than other taxa, while belonging quite clearly to independent subclusters (C. balcaricum, C. flexuosum, $C$. grande and $C$. nuristanicum). Closer study showed that these were among the species which had undergone the greatest taxonomic reclassification among previous classifications. Cicer anatolicum and C. balcaricum have been grouped together and referred to as series Anatolo-Persica (Popov) Lincz. in previous classifications, but appear quite separate in this analysis. Conversely, C. grande and C. korshinskyi are close in this analysis, which concurs with Van der Maesen's (1972) view that both are in series Flexuosa. Seferova keeps C. grande in series Flexuosa but moves C. korshinskyi to series Anatolo-Persico-Orientale. Many of the species in this group appear to form small tight groups rather than larger clusters. So, while this analysis has clustered $C$. kermanense, $C$. spiroceras and $C$. oxyodon with $C$. baldshuanicum and $C$. mogoltavicum, the former group of 3 species has been recognised as a distinct group (series Persica). Cicer baldshuanicum was placed with C. mogoltavicum in series Flexuosa Lincz. by Van der Maesen (1972). Seferova (1995) retained $C$. baldshuanicum in series Flexuosa Seferova and recombined C. mogoltavicum as $C$. flexuosa subsp. mogoltavicum Popov.

It is interesting to note that many species with similar geographical distribution are also linked by the results of the analyses. This either implies that the characters used here to segregate the taxa are heavily biased towards those influenced by geography or environment or they represent suites of characters which, when combined, are not independent within Cicer. Cicer songaricum, C. microphyllum and C. anatolicum, while appearing morphologically very similar, can be distinguished by their allopatric distribution: C. songaricum is confined to Central Asia, while C. microphyllum and C. anatolicum are from Kashmir and Turkey, respectively (Van der Maesen, 1987).

\section{Character suites and novel taxonomic hierarchy}

The multivariate analysis clearly indicated that the characters available for segregating taxa are very variable. Consequently, using only one or two features to delineate infrageneric groups will result in an indistinct, unstable hierarchy. This strongly argues 
for groups defined using many more characters, to account for the intrinsic variation. It also implies that morphology alone cannot be used to define the species relationships. The morphometric analyses did not reveal any novel taxonomically useful characters. Instead, the morphometric analysis allowed the definition of taxonomically useful character suites, whose variation allowed the circumscription of distinct groups. Thus, in a departure from conventional descriptions that restrict supraspecific descriptions to a few minimal characters, the subgenera, sections and series are defined by comparatively many characters.

Homoplasy (similarity not as a direct result of common ancestry) or repeated evolution of certain character traits within the genus, is clearly a disrupting factor for the development of a monophyletic infrageneric structure. Traditionally favoured characters, e.g., life cycle (annual : perennial) or rachis terminal structure (tendril : leaflet : spine) are particularly weak. By down-playing the importance of these characters in the definition of the infrageneric ranks of Cicer, and acknowledging the recent advances in molecular research of Cicer, it should be possible to construct a taxonomically useful infrageneric hierarchy that reflects interspecific relationships.

The revised classification proposed for Cicer is based on the morphometric analyses but take into account previously published hierarchies and the newly published molecular phylogenies.

The three subgenera Cicer, Viciastrum and Stenophyllum are distinguished on the basis of a suite of characters including habit (herbaceous : woody), life cycle (perennial : annual), terminal structure of rachis (tendril : leaflet : spine), leaf shape (outline parallel : outline decrescent), corolla size (standard long and broad : short and narrow) and filament length (long : short). The broad geographical distribution (African : Aegean-Mediterranean : West and Central Asia) is also important.

The sections and series in the subgenus Cicer are defined by the following suite of characters. Phyllotaxy (nearly opposite : alternate), stem height $(<20 \mathrm{~cm}:>20$ $\mathrm{cm}$ ), leaf base shape (rounded cuneate to cuneate), number of leaflet pairs on rachis (3-10:1-3(-7)), midrib tooth features ( \pm spinous : recurved : prominent), calyx teeth length ( $<7 \mathrm{~mm}:>7 \mathrm{~mm}$ ), seed length (c. 3-4 mm : c. $6 \mathrm{~mm})$, seed coat surface features (wrinkled : echinate : tuberculate). The hierarchy of the primary and secondary gene pool is acknowledged by the nomenclatural series Cicer and Pinnatifida within section Cicer. Seed storage proteins (Ahmad \& Slinkard, 1992, Sammour, 1994) and isozyme polymorphism data (Ahmad et al., 1992; Labdi et al., 1996; Tayyar \& Waines, 1996) corroborate this grouping, as do RAPD DNA analyses (Ahmad, 1999; Sudupak et al., 2002). Section Chamaecicer includes the two perennial species in this subgenus: C. atlanticum and $C$. incisum.

Subgenus Viciastrum is divided into three monophyletic sections: Annua, Polycicer and Vicioides s. ampl. Section Annua groups C. yamashitae and C. chorassanicum together. Subgenus Viciastrum section Polycicer forms a unified morphological subset within section Vicioides. The character traits defining and uniting the five taxa in Polycicer are also frequently found in various combinations in section Vicioides. However, the following character traits are unique to Polycicer: Habit (always herbaceous, flexuous 
stems); branching (mostly simple), leaf outline (always equal), leaflets (petiolate, always entirely dentate); raceme (1-many-flowered), arista (terminal clavate leaflet, not spinous); distribution (below $2000 \mathrm{~m}$ a.s.l. in Aegean-Mediterranean). The importance of the unique eco-geographic affiliation and the molecular phylogeny (Van der Maesen et al., 2007) of these species is recognised by the rank of section.

Subgenus Viciastrum section Vicioides s. ampl. indicates a significant shift in the supraspecific taxonomic hierarchy. Both the molecular data and several morphological analyses (e.g., Van der Maesen et al., 2007) indicate that the taxa within this group show a high degree of homoplasy, with parallel developments of character traits resulting in genetically distant (Van der Maesen et al., 2007) but morphologically similar taxa, i.e., C. oxyodon and C. spiroceras. These have 'traditionally' been the taxa whose precise taxonomic position has been most disputed and unstable. To avoid the persistent non-monophyletic artificial groupings that have characterised the description of these species' relationships in the past, the section Vicioides has been emended and amplified, and the subsectional ranks have been abandoned.

Subgenus Stenophyllum is robustly supported by both the morphological and molecular studies, and includes both $C$. canariense and $C$. cuneatum. This nomenclatural relocation of $C$. cuneatum and acknowledgment of its phylogenetic origin as closer to $C$. canariense has already been suggested by several authors (viz. Frediani \& Caputo, 2005; Javadi, 2004; Javadi \& Yamaguchi, 2004 a, b; Van der Maesen et al., 2007).

\section{INFRAGENERIC CLASSIFICATION OF CICER}

\section{Cicer}

Cicer L. (1753).

= Nochotta S. G. Gmel.

= Spiroceras $($ Jaub. \& Spach) Hutch., nom. invalid.

\section{Subgenus Cicer}

Cicer L. subg. Cicer. - Cicer L. subg. Pseudononis Popov (1929) 168, nom. illeg.; Maesen (1972) 18. - Type species: Cicer arietinum L.

Herbaceous (seldom woody at base) slender annual or perennials. Stems \pm densely pubescent with eglandular to glandular hairs. Leaf outline is equal, not decrescent. Terminal leaflet on leaves. Stipules laminate, usually smaller than leaflets. Leaflets laminate; cuneiform, obovate or elliptic; rarely flabellate, always dentate but sometimes only at apex; midrib tooth \pm prominent, \pm spinous, \pm recurved; petiolate, subsessile or sessile. Peduncles usually short $(0-15 \mathrm{~mm}$ long) but some species with longer peduncles (> $30 \mathrm{~mm}$ L.) Pedicels short or long. Calyx teeth straight; calyx tube short, $<5 \mathrm{~mm}$ long. Standard small, 5-10(-15) mm long, and narrow, 5-10(-15) mm wide; obovate to ovate; marginate or emarginate; pubescent or rarely glabrous; blue, pink or white. Alae shortly to longly auriculate or not auriculate; alae oblong or obovate. Filaments short, < $10 \mathrm{~mm}$ long. Pods oblong, or ovate; pubescence glandular or eglandular; seeds angular, globular or obovate; seed coat surface tuberculate, echinate, wrinkled or smooth, \pm prominent chalazal tubercle. 


\section{Section Cicer}

Cicer L. sect. Cicer. - Cicer L. sect. Arietaria Jaub. \& Spach (1842) 225, p.p. nom. illeg. - Cicer L. sect. Monocicer Popov (1929) 168, p.p. nom. illeg.; Maesen (1972) 18. - Grex Imparipinnata Alef. (1859) 357, p.p. - Type species: Cicer arietinum L.

Crop gene pools: primary and secondary.

\section{Series Cicer}

Cicer L. ser. Cicer. - Cicer L. ser. Arietina Lincz. ex Seferova (1995) 101, nom. illeg. - Cicer L. ser. Arietina Lincz. (1948) 296, nom. invalidum. - Type species: Cicer arietinum L.

Annual species, stem height $20-40 \mathrm{~cm}$, leaves arranged nearly opposite or alternately, $3-10$ pairs of leaflets on rachis, midrib tooth spinous, prominent, recurved; leaflet bases cuneate to rounded cuneate, calyx teeth $<7 \mathrm{~mm}$ (rarely more), Seed length c. $6 \mathrm{~mm}$, seed coat wrinkled or echinate.

Species examined:

Cicer arietinum L.; C. echinospermum P.H. Davis; C. reticulatum Ladiz.

\section{Series Pinnatifida}

Cicer L. ser. Pinnatifida Seferova (1995) 102. - Type species: Cicer pinnatifidum Jaub. \& Spach. Cicer L. ser. Arietina auct. non Lincz.: Maesen (1972) 18, p.p. nom. invalidum.

Annual species, stem height $<30 \mathrm{~cm}$, leaves arranged nearly opposite, $2-10$ pairs of leaflets on rachis, midrib tooth \pm spinous, \pm recurved, leaflet bases cuneate, calyx teeth $<7 \mathrm{~mm}$ (rarely more). Seed length c. 3-4 mm, seed coat echinate or tuberculate.

Note - These species represent the secondary gene pool for the crop species. This grouping is reinforced by isozyme polymorphism data (Ahmad et al., 1992; Labdi et al., 1996; Tayyar \& Waines, 1996).

Species examined:

Cicer bijugum Rech.f.; $C$. judaicum Boiss.; C. pinnatifidum Jaub. \& Spach.

\section{Section Chamaecicer}

Cicer L. sect. Chamaecicer Popov (1929) 168, p.p. - Cicer L. sect. Nanopolycicer (Popov) Seferova (1995) 98. - Cicer L. subsect. Nanopolycicer Popov (1929) 169. - Cicer L. ser. Perennia Lincz. ex Maesen (1972) 19. - Cicer L. ser. Perennia Lincz. (1948) 298, nom. invalidum. - Grex Imparipinnata Alef. (1859) 357, p.p. - Type species: Cicer incisum (Willd.) K. Malý.

Cicer L. ser. Arietina auct. non Lincz.: Maesen (1972) 18, p.p. nom. invalidum.

Perennial creeping species, may be slightly woody at base, stem height $<20 \mathrm{~cm}$, leaves arranged opposite, 1-3(-7) pairs of leaflets on rachis, midrib tooth not spinous but can be prominent, leaflet bases cuneate, calyx teeth $<7 \mathrm{~mm}$ (rarely more); seed length 3-4 mm, seed coat tuberculate.

Species examined:

Cicer atlanticum Coss. ex Maire; C. incisum (Willd.) K. Malý.

\section{Subgenus Viciastrum}

Cicer L. subg. Viciastrum Popov (1929) 168; Maesen (1972) 19. - Lectotype: Cicer songaricum Steph. ex DC. (designated by Seferova, 1995). 
Herbaceous or woody perennial shrubs, seldom annual herbs. Terminal leaflet, spine or tendril on leaves. Stipules laminate or spiniferous, smaller or larger than leaflets. Leaf outline always decrescent. Leaflets laminate or spiniferous, cuneiform, obovate or rotund, occasionally flabellate, always dentate but sometimes only at apex, midrib tooth \pm prominent, \pm spinous, \pm recurved, petiolate, subsessile or sessile. Peduncles 16-45 mm long. Pedicels long (>6 mm). Calyx teeth straight (rarely recurved), tube 6-8 mm long. Standard large (12-)15-17(-27) $\mathrm{mm}$, and 10-16+ mm wide, obovate to ovate, marginate or emarginate, pubescent or glabrous, blue or white, seldom yellow. Alae shortly to longly auriculate, oblong, obovate or clavate. Filaments (6-)10-11+ mm long. Pods oblong, ovate or elliptic, glandular (seldom eglandular); seeds globular or obovate, tuberculate or wrinkled, \pm prominent chalazal tubercle.

\section{Section Annua}

Cicer L. sect. Аппиа (Maesen) Seferova (1995) 101. - Cicer L. ser. Аnnиa Maesen (1972) 19. - Cicer L. sect. Chamaecicer Popov (1929) 168, p.p. excl. typus. - Cicer L. ser. Macro-aristae Maesen (1972) 18. - Grex Imparipinnata Alef. (1859) 357, p.p. - Type species: Cicer chorassanicum (Bunge) Popov.

Annual erect to creeping species, can be slightly woody at base, stem height $<20 \mathrm{~cm}$, leaves arranged opposite, 1-3 pairs of leaflets on rachis, arista to $20 \mathrm{~mm}$ long, seed coat tuberculate.

Species examined:

Cicer chorassanicum (Bunge) Popov; C. yamashitae Kitam.

\section{Section Polycicer}

Cicer L. sect. Polycicer Popov (1929) 169. - Cicer L. ser. Graeca Seferova (1995) 97. - Cicer L. ser. Anatolica Seferova (1995) 97. - Cicer L. ser. Europaeo-Anatolica Popov (1929) 169. - Grex Imparipinnata Alef. (1859) 357, p.p. - Cicer L. sect. Arietaria Jaub. \& Spach (1842) 230, p.p. - Lectotype: Cicer montbretii Jaub. \& Spach (designated by Seferova, 1995).

Herbaceous, erect perennials. Flexuous stems with simple to rarely secondary branching. Leaf outline equal, leaflets evenly spaced on rachis $(<2$ leaflets per $\mathrm{cm})$, rachis laminate or tendrilous but never spiniferous, stipules laminate. Leaflets 3-10 pairs, petiolate, $(6-10)>11$ by $>4 \mathrm{~mm}$, margins entirely dentate, $>12$ teeth per leaflet, midrib tooth \pm recurved. Raceme 1-many-flowered, arista with terminal clavate leaflet. Calyx strongly dorsally gibbous, medium to longish pubescent (hairs $>0.6 \mathrm{~mm}$ ), calyx teeth $>9 \mathrm{~mm}$ long. Standard 12-15 mm long, seldom longer, 10-15 mm wide. Alae 11-15(>16) $\mathrm{mm}$ long. Occurs below $2000 \mathrm{~m}$ in the Aegean-Mediterranean.

Species examined:

Cicer floribundum Fenzl; C. graecum Orph.; C. heterophyllum Contandr., Pamukç. \& Quézel; C. isauricum P.H. Davis; C. montbretii Jaub. \& Spach.

\section{Section Vicioides}

Cicer L. sect. Vicioides Jaub. \& Spach (1842) 230, s. ampl. emend. Davies, Maxted \& Maesen. - Cicer L. sect. Spiroceras Jaub. \& Spach (1842) 232. - Cicer L. sect. Tragacanthoides Jaub. \& Spach (1842) 232. - Cicer L. sect. Polycicer subsect. Macro-polycicer Popov (1929) 169. - Cicer L. sect. Acanthocicer Popov (1929) 169. - Cicer L. ser. Anatolo-Persica (Popov) Lincz. (1948) 299. - Cicer L. ser. Anatolo-Perso-Orientalia Popov (1929) 169. - Cicer L. ser. Flexuosa 
Lincz. (1948) 299, nom. invalidum. - Cicer L. ser. Flexuosa Lincz. ex Seferova (1995) 98. - Cicer L. ser. Microphylla Lincz. (1948) 304, nom. invalidum. - Cicer L. ser. Macracantha Lincz. (1948) 307, nom. invalidum. - Cicer L. ser. Macracantha Lincz. ex Seferova (1995) 99. - Cicer L. ser. Persica Popov (1929) 169. - Cicer L. ser. Pungentia Lincz. (1948) 306, nom. invalidum. - Cicer L. ser. Pungentia Lincz. ex Seferova (1995) 99. - Cicer L. ser. Songorica Lincz. (1948) 303, nom. invalidum. - Cicer L. ser. Subaphylla Seferova (1995) 100. - Cicer L. ser. Tragacanthoidea Lincz. (1948) 308, nom. invalidum. - Cicer L. ser. Tragacanthoidea Lincz. ex Seferova (1995) 100. - Cicer L. ser. Anatolo-Perso-Orientalia Popov subser. Anatolo-Persica Popov (1929) 170. - Cicer L. ser. Anatolo-Perso-Orientalia Popov subser. Orientalia Popov (1929) 170. - Grex Apiculata Alef. (1859) 357. - Lectotype: Cicer songaricum Steph. ex DC.: Jaub \& Spach. (= C. anatolicum Alef.) (designated by Seferova, 1995).

Cicer L. ser. Flexuosa auct. non Lincz.: Maesen (1972) 19.

Cicer L. ser. Macracantha auct. non Lincz.: Maesen (1972) 20.

Cicer L. ser. Pungentia auct. non Lincz.: Maesen (1972) 20.

Cicer L. ser. Songorica auct. non Lincz.: Maesen (1972) 20.

Cicer L. ser. Tragacanthoidea auct. non Lincz.: Maesen (1972) 20.

Woody, erect to spreading perennials, straight to flexuous stems with secondary branching. Leaf outline decrescent, leaflets widely to evenly spaced along rachis $(<1$ or 2 leaflets per $\mathrm{cm})$, rachis laminate, tendrilous or spiniferous, stipules laminate or spiniferous. Leaflets (3-)10-15 pairs, subsessile to sessile, $<5->11$ by $<6 \mathrm{~mm}$, margins serrated to nearly entire, $<5-12$ teeth per leaflet, midrib tooth always recurved. Raceme 1- or 2-flowered, arista spiniferous. Calyx strongly or weakly dorsally gibbous, glabrous to shortly pubescent (hairs $<0.5 \mathrm{~mm}$ long), calyx teeth 5-12 mm long. Standard $12-27$ by $4-16 \mathrm{~mm}$. Alae $<10-15 \mathrm{~mm}$ long. Occurs between $1000-4000 \mathrm{~m}$ a.s.l. in West and Central Asia.

\section{Species examined:}

Cicer acanthophyllum Boriss.; C. anatolicum Alef.; C. balcaricum Galushko; C. baldshuanicum (Popov) Lincz.; C. fedtschenkoi Lincz.; C. flexuosum Lipsky; C. grande (Popov) Korotkova; C. incanum Korotkova; C. korshinskyi Lincz.; C. laetum Rassulova \& Sharipova; C. luteum Rassulova \& Sharipova; C. macracanthum Popov; C. microphyllum Benth.; C. multijugum Maesen; C. nuristanicum Kitam.; C. paucijugum (Popov) Nevski; C. pungens Boiss.; C. rassuloviae Lincz.; C. rechingeri Podlech; . songaricum Steph. ex DC.; C. stapfianum Rech.f.; C. subaphyllum Boiss.; C. tragacanthoides Jaub. \& Spach.

\section{Subgenus Stenophylloma}

Cicer L. subg. Stenophylloma A.G. Guerra \& G.P. Lewis (1985) 459. - Cicer L. sect. Cuneicicer Seferova (1995) 101. - Cicer L. ser. Cirrhifera Maesen (1972) 18. - Grex Cirrhifera Alef. (1859) 356. - Type species: Cicer canariense A. G. Guerra \& G.P. Lewis.

Perennial or annual, slender, semi-erect to trailing or climbing herb or shrub. Terminal simple or branched tendril on upper leaves at least. Stipules laminate, smaller than leaflets. Leaf outline equal, rachis loosely rolled. Leaflets laminate, linear or obovate, margins dentate, midrib tooth prominent, spinous, \pm recurved, pubescent, subsessile. Peduncles short or absent. Pedicels short. Calyx teeth straight, tube $<5 \mathrm{~mm}$. Standard short, (5-)10-12(-15) mm long and narrow, 5-10 mm wide, obovate, emarginate, pubescent, blue or pink. Alae shortly auriculate, obovate. Filaments (6-) $10-11+\mathrm{mm}$ long. Pods oblong, glandular; seeds globular, tuberculate, prominent chalazal tubercle. Occurs in Africa and the Canary Islands.

Species examined:

Cicer canariense A.G. Guerra \& G.P. Lewis; C. cuneatum Hochst. ex A. Rich. 


\section{ACKNOWLEDGEMENTS}

The authors would like to thank BM, E, K and WAG for the loan of specimens, and also Mr. and Mrs. I.J.B. Robertson and Dr. R. Davies for financial support and encouragement.

\section{REFERENCES}

Ahmad, F. 1999. Random amplified polymorphic DNA(RAPD) analysis reveals genetic relationships among the annual Cicer species. Theor. Appl. Genet. 98: 657-663.

Ahmad, F., P.M. Gaur \& A. Slinkard. 1992. Isozyme polymorphism and phylogenetic interpretations in the genus Cicer L. Theor. Appl. Genet. 83: 620-627.

Ahmad, F. \& A. Slinkard. 1992. Genetic relationships in the genus Cicer L. as revealed by polyacrylamide gel electrophoresis of seed storage proteins. Theor. Appl. Genet. 84: 688-692.

Alefeld, F. 1859. Ueber die Vicieen. Oesterr. Bot. Z. 9: 352-366.

Boissier, E. 1872. Flora Orientalis. Diag. Ser. 1, 9: 130-129; 2, 2: 43-44.

Brummitt, R.K. \& C.E. Powell. 1992. Authors of Plant Names. Royal Botanic Gardens, Kew,

Coles, S. 1993. The creation of identification aids for Cicer species. Unpublished MSc Thesis, University of Birmingham.

Coles, S., N. Maxted \& L.J.G. van der Maesen. 1998. Identification aids for Cicer (Leguminosae, Cicereae) taxa. Edinburgh J. Bot. 55: 243-265.

Contandriopoulos, J., A. Pamukçuoğlu \& P. Quézel. 1972. A propos de Cicer vivaces du pourtour Mediterranéen Oriental. Biol. Gallo-Hellen. 4-1: 3-18.

Davis, P.H. 1970. Cicer L. In: P.H. Davis (ed.), Flora of Turkey and the Eastern Aegean Islands, Vol. 3: 267-274. Edinburgh, Edinburgh University Press.

De Leonardis, I.S., G. Fichera \& A. Zizza. 1994. Morphological study of pollens and seeds on annual taxa of the genus Cicer L. (Leguminosae). Giorn. Bot. Ital. 127: 1101-1113.

Duncan, T. \& B.R. Baum. 1981. Numerical phenetics: its uses in botanical systematics. Annual Rev. Ecol. Syst. 12: 387-404.

Frediani, M. \& P. Caputo. 2005. Phylogenetic relationships among annual and perennial species of the genus Cicer as inferred from ITS sequences of nuclear ribosomal DNA. Biol. Pl. 49, 1: 47-52.

Hannan, R., N. Açikgöz \& L.D. Robertson. 2000. Chickpeas (Cicer L.). In: N. Maxted \& S.J. Bennett (eds.), Plant genetic resources of legumes in the Mediterranean: 113-122. Dordrecht, Kluwer Academic Publishing.

Holmgren, P.K., N.H. Holmgren \& L.C. Barnett (eds.). 1990. Index Herbariorium I: The herbaria of the world (ed. 8). New York: New York Botanical Garden.

Jaubert, H.F. \& E. Spach. 1842. Monografia generis Cicer. Ann. Sci. Nat., Bot. sér. 2, 18: 228-231.

Javadi, F. 2004. Molecular phylogeny of the genus Cicer L. (Fabaceae). PhD thesis, Osaka Prefecture University, Department of Agriculture and Biological Sciences: 1-169.

Javadi, F., M.F. Wojchiechowski \& H. Yamaguchi. 2007. Geographical diversification of the genus Cicer (Leguminosae: Papilionoideae) inferred from molecular phylogenetic analyses of chloroplast and nuclear DNA sequences. Bot. J. Linn. Soc. 154: 175-186.

Javadi, F. \& H. Yamaguchi. 2004a. Interspecific relationships of the genus Cicer L. (Fabaceae) based on trnT-F sequences. Theor. Appl. Genet. 109: 317-322.

Javadi, F. \& H. Yamaguchi. 2004b. RAPD and seed coat morphology variation in annual and perennial species of the genus Cicer L. Genet. Resources Crop Evol. 51: 783-794.

Javadi, F. \& H. Yamaguchi. 2004c. A note on seed coat and plumule morphological variation in the genus Cicer L. (Fabaceae). Sci. Rep. Grad. Sch. Agric. \& Biol. Sci., Osaka Pref. Univ. 56: 7-16.

Kabir, G. \& R.M. Singh. 1990. Karyotype analysis of six species of Cicer L. Bangladesh J. Bot. 19: $175-181$.

Kazan, K. \& F.J. Muehlbauer. 1991. Allozyme variation and phylogenetics in annual species of Cicer L. Pl. Syst. Evol. 175: 11-21.

Kupicha, F. K. 1977. The delimitation of the tribe Vicieae (Leguminosae) and relationships of Cicer L. Bot. J. Linn. Soc. 74: 131-162.

Kupicha, F.K. 1981. Vicieae. In: R.M. Polhill \& P.H. Raven (eds.), Advances in legume systematics: 377-381. Royal Botanic Gardens, Kew. 
Labdi, M., L.D. Robertson, K.B. Singh \& A. Charrier. 1996. Genetic diversity and phylogenetic relationships among the annual Cicer species as revealed by isozyme polymorphism. Euphytica 88: 181-188.

Ladizinsky, G. 1975. A new Cicer from Turkey. Notes Roy. Bot. Gard. Edinburgh 34: 201-202.

Ladizinsky, G. \& A. Adler. 1976. Genetic relationships among the annual species of Cicer L. Theor. Appl. Genet. 48: 197-203.

Linczevski, I.A. 1948. Cicer L. In: V.L. Komorov (ed.), Flora of the U.S.S.R. 13: 294-309. MoskovaLeningrad, Izdatelstvo Akademii Nauk S.S.S.R.

Linnaeus, C. 1753. Species Plantarum ed. 1: 738.

Maxted, N. 1993. A phenetic investigation of Vicia L. subgenus Vicia (Leguminosae, Vicieae). Bot. J. Linn. Soc. 111: 155-182.

Muehlbauer, F.J., W.J. Kaiser \& C.J. Simon. 1994. Potential for wild species in cold season food legume breeding. Euphytica 73: 109-114.

Nozzolillo, C. 1985. Seedling morphology and anatomy of 8 Cicer L. species and their taxonomic value. Canad. J. Bot. 63: 1-6.

Ocampo, B.G., A. Venora, A. Errico, K.B. Singh \& F. Saccardo. 1992. Karyotype analysis in the genus Cicer L. J. Genet. \& Breed. 46: 229-240.

Popov, M.G. 1929. The genus Cicer and its species. Trudy Prikl. Bot. 21: 1-254.

Rajesh, P.N., V.J. Sant, V.S. Gupta, F.J. Muehlbauer \& P.K. Ranjekar. 2003. Genetic relationships among annual and perennial wild species of Cicer using Inter Simple Sequential Repeat (ISSR) polymorphism. Euphytica 129: 15-23.

Rassulova, M.R. \& B.A. Sharipova (eds.). 1978. Flora Tadzhikskoi S.S.R. 5: 562-634.

Rassulova, M.R. \& B.A. Sharipova. 1992. New species of the genus Cicer from Tajikistan. Izv. Akad. Nauk Tadziksk. SSR 1: 51-52.

Robertson, L.D., K.B. Singh, W. Erskine \& A.M. Abd el Moneim. 1996. Useful genetic diversity in germplasm collections of food and forage legumes from West Asia and North Africa. Genet. Resources Crop Evol. 43: 447-460.

Rohlf, F.J. 1995. NTSYS - pc: Numerical taxonomy and multivariate analysis systems. New York, Exeter Software.

Sammour, R.H. 1994. Seed protein homology and species relationships in the tribe Vicieae. Feddes Repert. 105: 191-196.

Santos Guerra, A. \& G.P. Lewis. 1985. A new species of Cicer (Leguminosae-Papilionoideae) from the Canary Islands. Kew Bull. 41: 459-462.

Seferova, I.V. 1995. Konspekt sistemy roda Cicer (Fabaceae). (The synopsis of the system of genus Cicer (Fabaceae)). Bot. Zhurn. (Moscow \& Leningrad) 80-8: 96-104.

Sudupak, M. 2004. Inter and intra-species Inter Simple Sequence Repeat (ISSR) variations in the genus Cicer. Euphytica 35, 2: 229-238.

Sudupak, M., M. Akkaya \& A. Kence. 2002. Analysis of genetic relationships among perennial and annual Cicer species growing in Turkey using RAPD markers. Theor. Appl. Genet. 105, 8: $1220-1228$.

Sudupak, M., M. Akkaya \& A. Kence. 2004. Genetic relationships among perennial and annual Cicer species growing in Turkey assessed by AFLP fingerprinting. Theor. Appl. Genet. 108, 5: 937-944.

Sudupak, M. \& A. Kence. 2004. Genetic relationships among perennial and annual Cicer species growing in Turkey as revealed by allozymes. Genet. Resources Crop Evol. 51, 3: 241-249.

Tayyar, R.I. \& J.G. Waines. 1996. Genetic relationships among the annual species of Cicer (Fabaceae) using isozyme variation. Theor. Appl. Genet. 92: 245-254.

Van der Maesen, L.J.G. 1972. Cicer L., A monograph of the genus with special reference to the chickpea (Cicer arietinum L.), its ecology and cultivation. Meded. Landbouwhoogeschool Wageningen 72-10: 9-136.

Van der Maesen, L.J.G. 1987. Origin, history and taxonomy of the chickpea. In: M.C. Saxena \& K.B. Singh (eds.), The chickpea: 11-34. Wallingford, CAB International.

Van der Maesen, L.J.G., N. Maxted, F. Javadi, S. Coles \& A.M. Davies. 2007. Taxonomy of Cicer revisited. In: S.S. Yadav, R. Redden, W. Chen \& B. Sharma (eds.), Chickpea breeding and management: 14-46. CABI International. 


\section{IDENTIFICATION LIST}

\begin{tabular}{|c|c|c|}
\hline \multicolumn{3}{|r|}{ (2) } \\
\hline $1=$ anatolicum & $12=$ graecum & $23=$ pinnatifidum var. anatolicum \\
\hline $2=$ arietinum & 13 = incisum & $24=$ pinnatifidum var. pinnatifidum \\
\hline $3=$ atlanticum & $14=$ isauricum & $25=$ pungens \\
\hline $4=$ bijugum & 15 = judaicum & $26=$ rechingeri \\
\hline $5=$ canariense & 16 = kermanense & $27=$ reticulatum \\
\hline $6=$ chorassanicum & 17 = macracanthum & $28=$ songaricum \\
\hline 7 = cuneatum & 18 = microphyllum & $29=$ spiroceras \\
\hline 8 = echinospermum & $19=$ montbretii & $30=$ subaphyllum \\
\hline $9=$ fedtschenkoi & $20=$ multijugum & $31=$ tragacanthoides var. tragacanthoides \\
\hline 10 = flexиоsиm & $21=$ nuristanicum & $32=$ tragacanthoides var. turcomanicum \\
\hline 11 = floribundum & $22=$ oxyodon & $33=$ yamashitae \\
\hline
\end{tabular}

Aitchison 740: 18 - Akhtar 706/45: 6 - Alava 7067: 23; 10591: 6 - Alston \& Sandwith 1642: 19 - Andrews R117: 5 - Archibald 2187: 1 - Aryavand, Edmondson \& Miller 1420: 29 - Assadi, Edmundson \& Miller 1681: 16 - Atchley 627: 12.

A. Baytop 20127a: 4 - A. Baytop \& T. Baytop 2583: 19 - Biggs 13153: 16 - J. Bormüller \& A. Bormüller 6634: 22; 6635: 22 - Bowes 88: 17 - Brown \& Rothera 15: 18.

Carter 542: 20 - Clarke 28716B: 17 - Cosson 1873 (BM-type): 3; 1876 (BM-type x2): 3.

Daly 1246: 31 - Davis 42876: 8; 43077: 24 - P.H. Davis 307: 13; 4339: 15; 18119: 13 - Davis \& Hedge 27464: 24; 28545: 8; 29090: 23; 29179: 23; 29402: 1; 31201: 13; 31766: 1 - Davis \& Polunin 24751: 1 - De Wilde 7041: 7.

E00032291: 18 - Edmondson 1207: 32.

Fouroughi, Sanii \& Amini 12347: 29 - Furse 2568: 31; 2624: 22; 5692: 6; 8396: 6 - Furse \& Synge 427: 22.

Gillet \& Rawi 7669: 4.

Hedge \& Wendelbo 4202: 25; 4415: 25; 4525: 25; 5225: 26; 5348: 9; 8793: 31.

Kerr 2422: 2 - Kie 2378: 25 - Kotschy 403: 30.

Lemperg 434: 12 - Litinow 388: 32 - Ludlow 356: 18 - Ludlow \& Sherriff 8399: 18; 8547: 18.

Markova et al. 932: 19 - Massodegh 15: 29- Maxted, Allkin \& Khattab 4699: 19 - Maxted, Auricht \& Kitiki 4843: 8; 5043: 8; 5230: 8 - Maxted, Ehrman, \& Khattab 1870: 15; 1877: 15 — Maxted, Ladizinsky \& Potokina 8045: 10; 8048: 10; 8062: 10 — Maxted \& Sperling 8201: 28; 8234: 28 - Musselman 10329: 15.

Noë 174: 19.

Orphanides 495: 13.

Pappi 138: 7; 6352: 7 - Polunin et al. 695: 2; 1197: 18 - Punjab Department of Agriculture Type 14: 2; Type 20: 2 .

Rabmanian 6321: 31 - Rechinger 10443: 22; 18720: 25; 37351: 20; 47970: 22; 53396: 32 - Roberts 566: 18 - Rowe \& Sproul 34: 9.

Schimper 270 (BM-isotype): 7; 810 (BM-isotype): 7; 1545 (BM-isotype): 7 - Siddiqui 4130: 18 - Southampton University 125: 18 - Stainton 2672: 21; 2691: 17 - Stapf 1294: 22.

Van der Maesen 1347: 14; 2022: 33; 2023: 33; 2024: 33; 2058: 11; 2060: 11; 2100: 27; 2103: 4; 2105: 27; 2106B2: 27; 2211: 26; 2214: 26; 2765: 14; 3212: 12; Sdl. 1033-68: 10.

Wheeler Haines W1544: 4.

Zohary \& Amdursky 345: 15.

From the literature: Contandriopoulos et al. (1972): C. heterophyllum; Van der Maesen 1972, 1987; Davis, 1970; Maxted, 1993; Kupicha, 1977; Coles, 1993: C. acanthophyllum; C. balcaricum; C. baldshuanicum; C. grande; C. incanum; C. korshinskyi; C. mogoltavicum; C. paucijugum; C. stapfianum. 